\title{
GONORRHOEA AND ITS PSYCHOLOGICAL CASUALITIES
}

\author{
By KENNETH WALKER, F.R.C.S., \\ Lecturer in Venereal Disease at St. Bartholomew's Hospital ; \\ Genito-urinary Surgeon to St. Paul's and the Royal Northern \\ Hospital
}

As a small boy I learned that although the ostrich could run faster than a horse, it could eventually be overtaken because it had never learned the art of running in a straight line. As a mature man, I have discovered that the zig-zag may be the method of progression, not only of ostriches, but also of medical men.

No better example of this could be found than the attitude of the profession in the last thirty years to urethral infections. At the commencement of that period urethral infections were treated with contempt. As a dresser at Barts I prescribed " Haustus Cubebs et Copaiba" and repeated the mixture until the patient disappeared or declared himself to be cured. At that time gonorrhœa was a minor ailment unworthy of the attention of even a dresser. Only slowly did it dawn on the profession that a gonococcal infection was not a negligible trouble, and that it was responsible for a vast amount of ill-health and human unhappiness. The war hastened this change of view, for whole army corps were immobilised in the venereal camps of Europe, and, as a result, the work of slaughter was seriously handicapped. The outbreak of V.D. in the army was associated with one in the civil population. Public bodies and voluntary organisations were galvanised into activity, and an intensive campaign was instituted against all organisms that had lodged in the genital tract.

It is far from my intention to underrate the importance of dealing thoroughly with gonococcal infections or to suggest that the modern attitude to them is not immeasurably better than the old. I would merely suggest that in our anxiety not to miss a focus of infection we may run the risk of losing our sense of proportion and of swinging from one extreme of under treatment to the 


\section{GONORRHEA}

opposite one of over treatment. The following case sheets taken from my records will illustrate best what I mean.

F. W. D. consulted me first in I930. When in Sumatra four years previously he had suffered from a mild urethral irritation. There was no reason to suspect a gonococcal infection, since he had only once indulged in intercourse and on that occasion had worn a rubber sheath. Only Gram positive gonococci could be found in the urine, but, in spite of this, energetic treatment was immediately instituted. As the irritation increased under this treatment, the patient decided to leave the east and to consult a Parisian authority on venereal infections. This authority acted with great promptness. Posterior urethroscopy having revealed the presence of a small " polypus," it was fulgurated. The discharge, if anything, became more marked after this operation, and a diagnosis of chronic vesiculitis was made. For this a bilateral Belfield operation was recommended and performed. Undeterred by the fact that this operation had failed to relieve his symptoms, the patient agreed to its repetition when he returned to the east. Induration of Cowper's glands was then noted by his medical adviser, and since these structures could easily be dispensed with they were immediately excised. As the patient was now showing signs of an anxiety neurosis, operative measures were abandoned and a course of vaccine therapy instituted. Finally the victim despaired of cure and returned home to London in the hope that an English authority on vesiculitis could suggest some hitherto untried form of treatment. After consulting another specialist he arrived in my consulting room, a complete nervous wreck. It took three months of hard talking to persuade him that he had never suffered from venereal disease, and that it would be best for him to accept what was now a chronic infection of the urethra in as philosophical a spirit as possible. In the end, I even succeeded in convincing him that he might realise his ambition to get married. Before doing so, he asked me to test his semen in order to make certain that he was fertile. An examination showed complete azoospermia-the legacy of his repeated Belfield operations. If ever there was a human being who had suffered at the hands of physicians, it was he.

A. B., aged twenty-four, three years previous to con- 


\section{BRITISH JOURNAL OF VENEREAL DISEASES}

sulting me, had contracted gonorrhœea, and had placed himself in the best hands in the Harley Street neighbourhood in order to be cured. At the end of a few months' treatment the discharge had disappeared, but he was assured that it was necessary for him to have prostatic massage in order to get rid of the last traces of his trouble. The massage went on for two years, sometimes once and sometimes twice a week, in spite of the fact that the patient was plunging deeper and deeper into a state of neurasthenia. Even two attempts at suicide did not perturb the patient masseur of the prostate. At last he broke loose and even at the risk of offending medical etiquette consulted another authority. When I examined him, I found a normal prostate and a prostatic fluid that contained about three leucocytes per microscopic field. He was sent to Switzerland for a climbing holiday, and I have not heard of him since.

R. D., aged thirty-four, had developed a slight urethral discharge four weeks after coitus some five years previous to his consulting me. The doctor he had consulted at the time stated that it was gonorrhœa, and instituted treatment. The discharge was associated with frequency of micturition and discomfort in the perineum. After treatment the discharge disappeared, but the patient's sense of shame that he had contracted an immoral disease remained. From time to time, and particularly when he was run down from overwork, the pain in the perineum would return and he would notice a tendency to frequency of micturition. This recurrence of the old symptoms confirmed his worst suspicions that he was still infected, and he felt that he must remain a leper for the remainder of his life. On examining him I could find nothing abnormal, and considered both his pain and his frequency to be functional. I knew, however, that it was impossible to convince him that there was nothing wrong and told him that he was suffering from a slight congestion of the prostate that could easily be cured by appropriate treatment. This treatment, so far as he was concerned, consisted of diathermy followed by light massage of the prostate. Actually these measures provided a cloak for many conversations during which reassurance, suggestion and re-education were used. His symptoms slowly lifted, but from time to time he would hurry back from the Continent to see me with a 


\section{GONORRHEA}

slight return of perineal pain. The relapses became fewer and in the end, much to my delight, he returned from abroad with a German fiancée, asking my blessing on his marriage. I willingly gave it after explaining the situation to his future wife and enlisting her help. So ably did she second my efforts that despite the fact that she developed a bacillus coli infection during the honeymoon, we were able to prevent her husband from believing that he had infected his bride with gonorrhœea.

The deductions to be drawn from the above cases are that there are still to be found medical men who regard a urethral discharge as synonymous with gonorrhœa, and also specialists who are so conscientious in their treatment of a gonococcal infection that they consider signs of a growing neurosis in their patients as of no importance. Of the first of these two errors in judgment, it is unnecessary to speak in a journal of this kind, for a bacteriological examination of a discharge is regarded as an essential routine step in the handling of a patient. But the second mistake of regarding psychological symptoms as of minor importance is far less widely recognised. It cannot be too clearly appreciated that both venereal disease and the genital organs provide an excellent soil in which a neurosis may grow. Associated with the function of sex, the genital tract is intimately linked with the emotional life, and it is from an emotional conflict that a neurosis springs. Moreover, in spite of the broader outlook of modern times, venereal disease is still apt to carry with it a moral stigma. He who suffers from it feels cut off from his fellows, inferior and guilty. Small wonder, therefore, that the sufferer from venereal disease, if he be of the psychopathic type, is an easy prey to functional troubles. By our propaganda we have deliberately spread the fear of venereal contagion, and venereo-phobia is undoubtedly on the increase. From the old extreme of regarding venereal disease as a minor ailment, the pendulum has swung in the opposite direction, so that the public now believe that it is as dangerous as cancer, and the psychopathic patient who has actually contracted it is convinced that he will never be cured.

Eventually the middle way between these two extremes will be found, but in the meantime it behoves us to keep in mind the psychological state of a patient as well as the physical condition of his urethra. 


\section{$\mathrm{V}$ \\ FRANK KIDD, F.R.C.S., M.Ch.}

WE regret the loss of Mr. Frank Kidd, F.R.C.S., M.Ch., who died suddenly on May I2th.

$\mathrm{He}$ is well known for the important work with which he was associated in the early days of the crusade against the spread of venereal diseases.

The establishment by Frank Kidd of a clinic for venereal diseases at the London Hospital in I9I4 was an achievement of fundamental importance, the beneficial results of which are incalculable.

He was present at a meeting held at the " Royal Society of Medicine " on June 9th, I922, when the idea of forming "The Medical Society for the Study of Venereal Diseases" was materialised. At the first Annual General Meeting, held in the rooms of the "Medical Society of London" on July 3Ist, I922, Mr. Frank Kidd proposed that Dr. David Watson should be elected as President. He was a member of the Council from July, I922, till June, I932. $\mathrm{He}$ was unable to attend as many of the meetings of the Council and of the Society as he would have liked, but his keen interest in its welfare never subsided.

Although many were acquainted with Frank Kidd, he was really known but to a few, to whom he showed by his staunchness and generosity that degree of thoroughness which distinguished his work as a genito-urinary surgeon.

To his widow and family we offer our sincerest sympathy. 